Sports Humanities

\title{
"I support you in everything": a qualitative study on maternal perception about their skating daughters
}

\author{
Anna Vitoria Rodrigues Renaux de Oliveira $^{1}$ (D), Claudia Ridel Juzwiak ${ }^{2}$ (D), \\ Ricardo da Costa Padovani ${ }^{3}$ \\ ${ }^{1}$ Universidade Federal de São Paulo, Programa de Pós-Graduação Interdisciplinar em Ciências \\ da Saúde, Santos, SP, Brazil; ${ }^{2}$ Universidade Federal de São Paulo, Departamento de Ciências do \\ Movimento Humano, Santos, SP, Brazil; ${ }^{3}$ Universidade Federal de São Paulo, Departamento de \\ Saúde, Educação e Sociedade, Santos, SP, Brazil.
}
Associate Editor: Giselle Tavares (D. Universidade Federal de Uberlândia, Uberlândia, MG, Brazil. E-mail: ghtavares@ufu.br.

\begin{abstract}
Aim: The study aimed to understand the perceptions of mothers about the practice of figure skating by their daughters aged between 8 and 13 years old. Methods: Eight mothers of skaters belonging to a youth competition team were interviewed in a qualitative study, which used narratives as the methodological approach. The interview was structured with open-ended questions and the full transcriptions were analyzed through content analysis. Results: The results of the three categories of analysis - "Skating and competing: the first influences"; "Family models and maternal participation"; and "Behavior of parents in sporting events" - showed that mothers perceived they provide emotional and motivational support during their daughters' sports practice and that they do not exert pressure for results. To not recognize negative behaviors could be negative to the skaters and may be the result of an inconscient mechanism or the need of mothers to have socially accepted behavior. They also stressed anxiety during competitions and reported strategies to cope with it. Thus, it is important to raise awareness of this situation so mothers can have more resources to manage this fragile balance. Conclusions: The way mothers participate in their children's sports life and express their support influences their sports practice; therefore, to understand how mothers perceive their involvement in their daughters' sportive practice is important to develop best practices to guarantee the quality of the interaction between mothers-children and healthy psychological development.
\end{abstract}

Keywords: sport psychology, mother-child relationship, athletes.

\section{Introduction}

Many are the reasons that lead children and adolescents to sports practice - amongst which, learning new abilities, having fun, belonging to a group, experimenting with new challenges when competing, and the desire to win ${ }^{1}$. However, there is a growing tendency towards early entry into a competitive sport, aiming to obtain optimal performances and results. This may be problematic for a healthy physical and psychological development ${ }^{2-4}$.

As childhood is the stage of development in which sports initiation is more frequent and sports specialization is increasingly happening, parents become important actors in these processes. For young athletes to develop their sporting potential, both the characteristics of involvement and the way parents participate have an impact on their physical and emotional wellbeing $^{2,5}$.

The way parents express their emotional support creates opportunities for athletes' development of inde- pendence and autonomy. Furthermore, how they encourage and monitor sports practice, and keep track of the development of their children, exerts an important influence on their children's psychological and sport development $^{2,5-7}$. Ferreira and Moraes ${ }^{8}$ found that having siblings or parents who practiced sports, as well as parental admiration for the sport chosen by their children, influenced behaviors that encouraged the sports initiation of Olympic medal swimmers.

The importance of parents' role in their children's athletic development is also perceived by coaches, as shown by Nunomura and Oliveira ${ }^{9}$ in a study with coaches of formative categories of competitive artistic gymnastics in Brazil. Their results indicated that coaches recognized the benefits of parents' participation, i.e., how they encourage and support sports practice, their responsibility in transporting athletes to and from the training set, and how they monitor the training and the coaches' work. However, coaches also pointed out negative aspects, such as conflicts among athletes' parents, financial interests, indiffer- 
ence towards the youths' sports career, excessive expectations, and criticism.

If, on the one hand, parental intervention positively influences the child's sports practice, on the other, excessive intervention has negative consequences, which may impair the child's sports development ${ }^{9}$. The complexity that parents of children and adolescent athletes face to find a healthy way to manage the demands of the competitive environment is pointed out in a study by Lienhart et $\mathrm{al}^{7}$. The authors aimed to comprehend the stressors and the coping experiences of parents in the context of competitive sports. They highlighted stressors associated with time, financial and logistical aspects, health, and education. As examples of coping strategies, the authors emphasized the search for information, the management of emotional situations, the way the situations were controlled, and the provision of social and affective support.

When analyzing the literature referring to children's involvement in sport, Weinberg and Gould ${ }^{1}$ highlighted that one of the main reasons that lead children to quit sports is to not feel important or competent in the activity. The authors also indicated the benefits of the bonds provided by sports practice in their psychological development, since the feeling of affiliation and belonging is an important motivator that leads them to practice sports.

Such considerations express the complexity of the relationships established between parents and children in their insertion into competitive sports. This complexity becomes more delicate when the guidance in sports for the young athlete turns into the quest for results and high performance. At this point, both the psychological and physical health of the young athlete may be at risk, possibly leading to physical and/or mental suffering and illness. Weinberg and Gould ${ }^{1}$ emphasized that the increased interest in investigating the role that parents play in the participation of children and adolescents in sports was due to the adverse effects observed in their relationships.

Despite the relevance of this theme, no study was identified in Brazil that investigated parents' perceptions about the participation of their children in figure skating competitions, regardless of gender. Given the importance of parents in the sports practice of children, the present study aimed to understand the perceptions of mothers about the practice of figure skating by their daughters aged between 8 and 13 years old.

\section{Participants and methods}

\section{Context}

The present study is part of a broader study entitled "Effects of a mental training program for figure skating athletes", the objective of which was to evaluate the effects of an intervention program for the teaching and development of psychological skills for children and adolescent figure roller skating athletes.

\section{Study design}

It is a qualitative study in which narratives were used as the methodological approach. Based on narratives that emphasized a certain aspect of life $^{10}$, we explored mothers' perceptions within their daughters' sports trajectories. The narratives made it possible to understand the intricate context of interrelationships between mothers and skaters, as they allowed access not only to experiences but also their meanings.

\section{Participants}

Participants were responsible for the skaters who were part of a competitive figure skating team of a sports club in a city in the state of São Paulo, Brazil. The competition team was composed of 14 female athletes, aged from 8 to 13 years old (being female was not a condition to be part of the team, but a characteristic of this group). As inclusion criteria, participants had to have time available to take part in the interviews during or after their children's training and had their daughters participate in the other stage of this research (comprising a sport psychology intervention program). Invitations were conducted through face-to-face contact. Participant's characteristics are described in Table 1.

Of the total of 14 invitations, eight mothers accepted and met the inclusion criteria to participate in the study.

Table 1 - Characteristics of the participants.

\begin{tabular}{|c|c|c|c|c|}
\hline Participant & Age & Scholarity & Sport history & $\begin{array}{c}\text { Daughter's } \\
\text { age }\end{array}$ \\
\hline R1 & 48 & $\begin{array}{l}\text { College } \\
\text { Graduate }\end{array}$ & $\begin{array}{c}\text { Amateur figure skater. } \\
\text { Husband was an ama- } \\
\text { teur tennis player. }\end{array}$ & 10 \\
\hline R2 & 43 & $\begin{array}{l}\text { College } \\
\text { Graduate }\end{array}$ & $\begin{array}{l}\text { Older daughter baller- } \\
\text { ina and ex-golf athlete }\end{array}$ & 9 \\
\hline R3 & 35 & $\begin{array}{l}\text { College } \\
\text { Graduate }\end{array}$ & $\begin{array}{l}\text { Weight training and } \\
\text { yoga. Husband was a } \\
\text { professional football } \\
\text { player. }\end{array}$ & 10 \\
\hline R4 & 39 & $\begin{array}{l}\text { College } \\
\text { Graduate }\end{array}$ & $\begin{array}{l}\text { Weight training, just } \\
\text { like her husband. }\end{array}$ & 8 \\
\hline R5 & 42 & $\begin{array}{l}\text { College } \\
\text { Graduate }\end{array}$ & Weight training & 13 \\
\hline R6 & 36 & Postgraduate & $\begin{array}{l}\text { Was a ballerina and } \\
\text { currently does weight } \\
\text { training. }\end{array}$ & 13 \\
\hline R7 & 42 & $\begin{array}{l}\text { College } \\
\text { Graduate }\end{array}$ & $\begin{array}{l}\text { Jogging. Husband is a } \\
\text { physical education } \\
\text { professional. }\end{array}$ & 13 \\
\hline R8 & 42 & Postgraduate & $\begin{array}{l}\text { Jogging, figure skat- } \\
\text { ing, and yoga with her } \\
\text { daughter. Husband is a } \\
\text { surfer. }\end{array}$ & 9 \\
\hline
\end{tabular}


Being a mother was not an inclusion criterion to be part of this study, but a characteristic of this group, as mothers had more available time.

To guarantee anonymity participants were identified by the letter $\mathrm{R}$ followed by a number.

\section{Procedures}

Initially, one of the authors (AVRO) contacted the skating team's coach, who expressed interest and agreed to mediate the contact with the skaters' responsible. Subsequently, the research project was presented to the athletes' mothers who agreed in participating in the study, and also consented to the participation of their daughters in the other stage of the research. The study had a second stage of intervention, the results of which will be published elsewhere. The study was approved by the Research Ethics Committee of the Universidade Federal de São Paulo under appraisal \#2.035.089. Participation in the study was formalized by signing the Free and Informed Consent Form.

To obtain the narratives, semi-structured interviews were conducted. The interview is a research technique that allows social interaction between researcher and participant, and the construction of pertinent information to answer the research object from the experiences and behaviors of the interviewees ${ }^{10,11}$. The script, consisting of 18 open questions structured in three blocks, was developed by authors AVRO and RCP, based on the hypothesis and objectives of the study. The first block of questions investigated the skaters' insertion in the sport and their initiation in competitions. The second block aimed to investigate the skaters' family sports history, including questions about the families' sports practice, the families' participation in the children's sports life, and the perception of mothers on their influence. Finally, the last block of questions sought to understand the feelings and behaviors of mothers and their skating daughters in training and competitions. The blocks were grouped in themes and degree of complexity of cognitive and emotional answers ${ }^{12}$. The third author (RCP), a specialist in sport psychology, analyzed the construction, redaction, sequence, and the number of questions, from the simplest to the most complex to answer ${ }^{12}$.

The interviews were conducted by the first author and took place on the premises of the skaters training club, in a reserved place to guarantee the interviewee's privacy. Each mother was interviewed once, and the interviews lasted approximately $30 \mathrm{~min}$. Interviews were recorded in audio, and their content was transcribed ipsis litteris by the first author, maintaining the colloquialism of the speeches. The selected excerpts from the interviews were translated into English by the second and third authors, who are proficient in the language, respecting to the maximum the idiomatic expressions and slang used by the participants. Conventions were used in transcribing interviews to indicate pauses, laughs, etc., and guarantee the most reliable record of speeches possible. The transcriptions were conducted right after each interview. After one week the first author reviewed the recording and transcriptions.

\section{Data analysis procedures}

Following the proposal of Minayo ${ }^{11}$, a thematic content analysis was carried out following three steps. The first step was the pre-analysis: after transcribed, the material was subjected to a free-floating reading for the apprehension of values, beliefs, and representations of content. Seven a priori codes were defined based on the study's hypothesis and interview questions: sport's choice; competition initiation; motivation for competition; influences; family participation; parental anxiety; coping strategies. This phase was conducted by the first and third authors separately and then compared to confirm the definition of the initial categories. The subsequent step involved intense and attentive reading sessions of the transcripts, followed by coding and the identification of context units from the mothers' narratives for each code. The interviewer's impressions and hypothesis were annotated. This phase was conducted by the first author and revised by the second and third authors. Lastly, two independent judges analyzed the material and met with the researchers when three final categories were defined, representing the consensus and patterns of interviews: "skating and competing: the first influences"; "family models and maternal participation" and "behavior of parents at sporting events". Researchers and judges agreed 100\%.

\section{Results and discussion}

The age of the participants ranged from 35 to 48 years old. All participants had completed higher education, with two having completed postgraduate studies, distributed in the following areas: education (1), health (2), and humanities (4). One was a housekeeper. All were married. Three mothers had one daughter each (R1, R3, and $\mathrm{R} 8$ ), and five of the mothers had two children each (R2, R4, R5, R6, and R7).

As shown in Table 1, all participants mentioned practicing sports presently, and in the past. Competitive sports history in the family was reported by three participants. For these families, the history of the parental sport (participation and expertise) may have influenced the perception of their children's participation in sport $^{13}$. However, other factors such as level of education, social class, and other social markers can also play a role.

\section{Skating and competing: the first influences}

The first category encompassed the initiation of daughters in figure skating. We sought to identify the mothers' perceptions of their daughter's choice of sports discipline, the motivations to start participating in competitions, as well as to keep competing. R1, R3, and R7 
mentioned the role of the social environment and peers' influence and their daughter's desire to skate as the main influences. The statements below exemplify these perceptions:

\footnotetext{
"It started with her friends, she looked and said: - 'I want to skate too', then she asked for toy skates and when I put it on her feet, she already skated away. Then she asked to take classes. It started as playing, seeing friends skating too. It was her initiative, I don't interfere much except to give support, I leave her free to do what she likes" (R1).
}

Peer influence was reinforced by R1 as the main reason for her daughter to initiate skating and parental influence was not considered in the maternal analysis. The perception of peer influence was also reported by R3 and R7.

"She was motivated because of her friends, but she already wanted to skate [...] I think first it was because she knew the sport, then it was for pleasure and love for skating" (R7).

The daughter's desire to skate was perceived by all participants, with exception of R3, as an important element to initiate participation in sport, as shown in the speech exerts below:

\footnotetext{
"It certainly came from her, it wouldn't be from me, I never skated, I never wanted to skate, and I didn't care for her to skate" (R5).

"She started skating at the age of four, of her own volition, I think she saw girls skating at the club we used to go to and who asked her to skate" (R4).

"She discovered skating, started to get discouraged in ballet and wanted skating, so I made the change $[\ldots]$ she chose it herself" (R6).

"She was the one who chose it, it was an unbelievable thing. I have always been passionate about skating, I thought it was beautiful, but I had never skated. When she was very little, I bought a little truck and she looked at that little truck, turned it upside down, and started to skate on top of it" (R8).
}

However, the values and beliefs of parents - in this case, mothers - may have influenced how they perceive their children's involvement and how they will interpret their experience ${ }^{6,9}$. Values and parental desires may include social status, parental projection, characteristics, and culture of sport, and value of competing. Not considering the parental role in this process may present itself as a cognitive avoidance of contemplating the effects, especially the negative ones, in this relationship. Cognitive avoidance does not allow contact with evidence of reality.

In this study, the sports practice presented itself as a potent element in the process of socialization, of establishing new affective bonds, capable of promoting feelings of belonging and pleasure provided by the sports activity itself, as corroborated by the literature ${ }^{1,5,13,14}$. Studies highlight that emotional and affective support, focusing on play and enjoyment and interest in the child's sport have an important role in guaranteeing their healthy psychological development ${ }^{1,14,15}$.

Regarding the trajectory of the sport of their daughters, the mothers also reported on the start of their participation in competitions. From the narratives below, mothers highlighted their daughters' desire to skate, and these mothers perceived how much coaches played a fundamental role in the initiation of children in competitions.

\footnotetext{
"It was also her request....My husband was against it because, in addition to the investment of time and money, we had to take it easy, he was a little afraid. But at the same time, I saw that she wanted to evolve in the sport and that when she wanted to compete, it would be a natural part of her evolution in the sport. In a given year, the coach talked to her and said that she had the chance if she wanted, and then she participated in a smaller competition... and from then on the coach started training her for the competitions (R1)".

"It was the coach, the mother doesn't encourage anything, I think it's not necessary. I don't like it because I think it's a lot of stress, I don't like it" (R3).

"It came from her, I think she wanted to try, to test her limits. If there is one thing I can do, it is like this, I am demanding [...] I tell her that she must do her best, she may not be the best of all, but it is her best" (R5).
}

Only one mother (R6) recognized her influence in competition. Probably the potential negative effects of competitive and social perceptions of skaters may be affected by the statements of their mothers.

\footnotetext{
"She said 'I want to participate', then there was a time when she said she didn't want to anymore, that she just wanted to take classes. Then I encouraged her and said that she had done very well" (R6).
}

The frequent contact between coaches and mothers was identified in a group of former Brazilian athletes of artistic gymnastics and highlighted the need to understand the importance of the relationship between athletes, coaches, and parents ${ }^{16}$. Krahenbühl et al. ${ }^{17}$ investigated the perceptions of elite coaches of Brazilian handball teams regarding the promotion of competitions aimed at children and youngsters. The authors pointed out the importance of coaches respecting the pedagogical assumptions of longterm sports training, and that when working with the basic categories one must respect the training capacity of children and young athletes rather than emphasize competition purposes.

The characteristics of parental educational practices provided at initiation may have favored the sports development and the initiation in competitions. This corroborates the importance of the quality of the relationship established between parents - in the case of this study, mothers - and coaches, as evidenced in the studies by Holt et al. ${ }^{5}$ and Madigan et al. ${ }^{18}$. However, it is important to point out that investigating the quality of the relationship established, especially in situations involving participation in the competition, should involve the perception of coaches and fathers as well. 
Fernandes ${ }^{19}$ also found in his study about the influence of parents of under-11 soccer players, that communication with coaches is considered essential for the proper sports development of the young athletes, guaranteeing their health in a broader sense. Entry into the competitive sport is marked by the adult presence, represented by coaches and parents. At first, the coach has an important role in identifying and providing the right moment for competitive initiation; in a second moment, parents appear as the main source of support but also a source of demand on performance. Studies indicate that the involvement of children and adolescents in competitive sport may be permeated by parental desires and pressures ${ }^{3}$, which deserve attention. Therefore, observing how this relationship is sustained, and how parents manage the stressors resulting from competitive sport, is of fundamental importance for healthy psychological development, aspects which are stressed by various researchers ${ }^{2,7,20}$.

Under this perspective, the study by Amado et al. ${ }^{15}$ reported the impact of the characteristics of this relationship on the psychological development of children involved in sports. The authors pointed out that parents who are perceived as a source of support were positively associated with meeting basic psychological needs, observed by the development of intrinsic motivation, pleasure, fun, and children's engagement in sport. Parental pressure to win, however, was negatively associated with satisfying psychological needs and intrinsic motivation. They also highlighted that the greater the tension resulting from parental pressure, the lower the sense of competence and autonomy in sports practice. This parental posture also contributes to reducing the feeling of fun and pleasure when performing the activity, which leads to reduced commitment and favors sport abandonment.

Thus, the main findings in this category indicated that mothers stressed their daughters' autonomy /desire in choosing skating but did not perceive their influence. However, they pointed out the influence of peers and coaches in their daughters' initiation into skating and competing, respectively.

For a mother to recognize that their behavior can be inadequate to the healthy psychological development of their daughters can be aversive. To avoid reflecting on this situation and considering that they are doing the right and the best for their daughters is a way to avert the emergency of anxiety and feeling guilt.

\section{Family models and maternal participation}

This category covered the mothers' reports on the influence of family members on their daughter's sporting life and shows how they perceived their role in their daughters' sporting life. The narratives suggested that mothers perceived differently theirs and the fathers' involvement in their daughters' sports lives.

\begin{abstract}
"The father certainly does not... he comes and appreciates, but he is not the biggest supporter of this [...] I always say: - 'so what, if you want, go, if you don't want, it's also fine'. I even discourage her a little, sometimes, I tell her to participate for fun, but if she starts taking it too seriously, if she fails to travel, fails to go out then I'm against it unless it's something that you want" (R8). "My husband helps with technical things, he cleans the skates, he sees which skates might be better for her, he takes care of this technical part a lot. I like to help with the clothes, the artistic part, the part of motivating her when she is not doing well, to come and talk to her. I see myself more in this support role, to be there when she needs it, to encourage her to have a better relationship with the coach, who is the one who guides her the best" (R1).
\end{abstract}

R4 and R5 consider that family did not influence or set itself as a model for their daughters to engage in skating.

"When she started, it was a phase when we weren't doing much (exercise)l [...] I think it's more from her (the desire to skate)" (R4).

"No, no... it's hers, it's her own will, she was born with it" (R5).

The narratives suggested that mothers perceived fathers participating in the most technical and punctual tasks, such as taking care of equipment and assisting and enjoying presentations. A similar result was found in a study with former athletes of rhythmic gymnastics and their parents, which revealed the tendency of mothers to provide daily and constant support through praising, direct care, frequent contact with the coaches, and making costumes for competitions, while fathers' assistance happened through financial and material support ${ }^{21}$. The effects of parental gender in relation to children's sport participation were also observed by Wilson et al. ${ }^{13}$ who found that the competitive sport history of fathers, but not of mothers, was associated with athletes' skill level. Such findings reinforce the importance of amplifying the understanding of the parental role in the development of their children's sport participation.

On the other hand, mothers perceived themselves as more participatory in the training routine, more involved with the artistic aspects of the sport, and exerting emotional and motivational support in competitions and training. However, the division of tasks of parents (i.e., technical versus emotional support) may be perceived by children as a way of care and attention. To perceive parental actions as complementary and not discordant or absent, may contribute to a healthy psychological development. In this regard, Amado et al. ${ }^{15}$ show that parental support is negatively related to boredom, while positively related to satisfaction of children's basic psychological needs which may, consequently, predict intrinsic motivation and enjoyment.

\footnotetext{
"I don't remember talking to her about it [skating]. It was the other way around, she was interested in the sport, and I was: 'Wow, how cool, she likes the same thing I like'. And as I know the pleasure of skating [participant gets emotional], look, I'm
} 
feeling emotional ... I found it interesting that she liked it too [...]" (R1).

"I support everything, whatever she wants, and we can offer it to her, we support her. I didn't want her to participate in competitions, but she does, so I'm going to support her, I'm going to encourage her, I'm going to motivate her, I'm going to call her attention when I think I have to call too" (R3).

"I think there has to be a commitment, I say: - 'Mommy is going to invest in skates which cost 2,000 reais, if you don't want to, tell me and I won't buy these skates'. Those skates I bought for her cost 2,400 , she already had one, but I bought a better one [...]" (R2).

When investigating the role of parents in the sporting trajectory of rhythmic gymnastics athletes, Nakashima et al. $^{6}$ identified that mothers, more often than fathers, were a more constant presence in their daughter's life, playing a role as friend and participating in both pleasant and frustrating moments for the athletes.

Our main findings in this category suggested that mothers realized that their influence and that of fathers are different, as they act in different aspects of the sport, mothers being closer to situations that involve anxiety and emotions. These results suggest that the closer and more constant maternal presence, the greater their influence on their daughter's sports career. While this may generate more encouragement and support, it can also lead to greater demands. Thus, it is important to raise awareness of this situation in mothers so they can have more resources to manage this fragile balance. Additionally, it is important to create conditions for fathers to increase their participation in children's sports routines.

This situation becomes more challenging when a sport is not their greatest interest or desire. To change fathers' values and beliefs may become necessary to lasting behavior changes. The involvement of fathers in partnership with mothers may contribute to the greater interest of children in sports development and enjoyment. The participation of parents providing support, encouragement, and guidance is very important especially in the early years of sports practice and during specialized years $^{13,14}$.

\section{Behavior of parents at sporting events}

This last category brought insights into the mothers' perceptions regarding the participation of their daughters in competitions. They reported that anxiety characterized by excessive preoccupation, fear, and insecurity was a common feeling to all of them. R1 also recognized to stay irritated, agitated, and distracted.

The speeches below represent how some of them felt during competitions and training, and how they dealt with their emotions in such situations.

\footnotetext{
"In competitions, I get anxious because I know that she will be anxious. I was extremely irritated with her; I had to walk away and leave her with her father because I realized that I disturbed her a lot that day. [...] I am worried about her being anxious, her
}

anxiety makes me anxious. I get mad at her, start fighting with her too. I start to forget things, I get disorganized, I feel a little insecure. Then, I don't know what to do, I do things without thinking, I'm going to do her makeup and she stomps out" (R1).

"I get worried, and automatically, worry leads to anxiety, right? It is a pre-wariness, I'm worrying about something that hasn't even happened yet, already thinking about the aftermath: - 'Oh, she will come crying for me, I will have to talk" (R3).

"I'm more worried that nothing goes wrong, not that she falls or doesn't go well, but that everything is just right: clothes, hair, schedule and stuff" (R7).

"At the time of the competition I am worried, but I am worried about her, about something happening, being unlucky, falling and getting hurt, or getting sad. My concern is more about how she will feel afterward, maybe because I have never been a competitive athlete, I have difficulty dealing with it" (R8).

The narratives illustrated the mothers' manifestations of anxiety during the skaters' competitions, such as the possibility of their daughters falling during the presentation. When they reported on the possibility of falling, two concerns were evident: risk of injury resulting from the fall and frustration due to poor performance. As figure skating is a sport that involves speed and jumping on wheels, falls are a possibility, and when they occur during presentations, they compromise both scoring and classification, generating feelings of shame and guilt. It is interesting to observe that in these narratives, the father figure is not mentioned in the preparation and psychological support in pre and competitive events.

In a study with athletes in the pre-infant category of artistic gymnastics Duarte et al. ${ }^{22}$ identified fear as the most frequent feeling due to the possibility of falls and the risk of injury or severe pain. The fear of getting hurt and making mistakes was also described by artistic gymnasts aged from 9 to 12 years $^{23}$, as well as from 12 to 17 years $^{24}$.

The narratives also pointed to avoidance as a possible strategy for these situations. As R1 reported, the behavior of asking someone to dress up her daughter allowing her to get away from the situation can be considered avoidance of the stressful situation that involves preparing the costume for the presentation. In other narratives, it was possible to see references to distracting behaviors, such as having fun in the crowd with another child (R4), taking pictures, and filming the competition (R8) as reported by the mothers:

\footnotetext{
"I move away, I try to move away. Sometimes I get someone to dress her up and she stays calm. Over the time I learned to deal with it, not only in sport" (R1).

"Oh, I don't know, I take a deep breath and let go. I keep telling her to stay calm, but my heart is racing faster than hers. When she is going to perform, I look, but sometimes I don't even want to see, but I always end up looking and filming. Then after it is over, it's time to see how she will get in, will she be well, it is a concern for her" (R8).

"Nothing specific, I try to think positive, I'm in the crowd. And I have my younger daughter who helps me to relieve the tension" (R4).
} 
The stressful potential of competitive sport and the emotional tension experienced by family members were evident. In this category, all the interviewed mothers clearly stated their anxiety in competitions and strategies to cope with it. Such emotional manifestations reflected not only their concern for the health and physical integrity of their daughters who, in the position of skating athletes, may suffer an injury, but may also represent their concern with how they will be perceived and evaluated by the social group in which they participate. Such issues show the complexity of the relationship established between mother-athlete.

\section{Conclusions}

The present study tried to understand the perception of mothers about their daughters' figure skating practice. Mothers perceived a greater influence of peers, coaches, and their children's own desire in the initiation of skating and competing. On the other hand, they perceived themselves as participative and effectively involved in their children's training and competitions, situations in which they feel anxious and try to apply strategies to cope with.

No participant reported perceiving to exert pressure for performance or result or to provoke any other situation that could harm the physical and emotional health of their daughters. To not recognize negative behaviors that could be negative to their children may be the result of an inconscient mechanism or the need to present a socially accepted behavior.

To increase the understanding of the influences on children's involvement in sports it would be recommended to include the perception of the skaters themselves, fathers, and coaches. This is one of the limitations of this study that should be taken into consideration with other limitations: the reduced number of participants which prevents the generalization of the results, as well as the lack of external validation of the semi-structured questionnaire. However, it should be stressed that the third author who participates in the development of the instrument is an expert in sport psychology and has extensive experience in the area investigated. It should be also considered that any interview is affected by the rapport between researcherparticipant and that the answers portrayed the interviewee's perceptions.

Despite the limitations, the present study cast light on an important phenomenon, which is female participation in competitive sports. We believe that the availability of mothers to participate in the study constitutes an important stage for them to think about their practice. To amplify the comprehension of how mothers perceive their involvement in their daughters' sportive practice is important to develop best practices to guarantee the quality interaction between mothers-children and health psychological development.

\section{Acknowledgments}

AVRO received a grant from the Coordenação de Aperfeiçoamento de Pessoal de Nível Superior-Brasil (CAPES).

\section{References}

1. Weinberg R, Gould D. Fundamentos da psicologia do esporte e do exercício. $6^{\mathrm{a}}$ Ed. Porto Alegre, Ed. Artmed; 2017.

2. Knight $\mathrm{CH}$, Dorsch TE, Osai KV, Haderlie KL, Sellars PA. Influences on parental involvement in youth sport. Sport Exerc Perform Psychol. 2016;5(2):161-78.

3. Myer GD, Jayanthi N, DiFiori JP, Faigenbaum AD, Kiefer AW, Logerstedt D, et al. Sports specialization, Part II: alternative solutions to early sport specialization in youth athletes. Sports Health. 2016;8(1)65-73. doi.

4. Nwankwo GO, Ekechukwu RO. Implications of psychosocial risks associated with adolescents' sports participation: need for sports counselling. J Adv Educ Res. 2020;5 (3):142-7. doi

5. Holt NL, Neely KC, Slater LG, Camiré M, Côté J, FraserThomas J, et al. A grounded theory of positive youth development through sport based on results from a qualitative meta-study. Int Rev Sport Exerc Psychol. 2017;10(1):1-49. doi

6. Nakashima FS, Nascimento Júnior JRA, Vieira LF. O papel dos pais na trajetória esportiva de atleta de ginástica rítmica. Pensar a Prática. 2012;15(4):852-69. doi

7. Lienhart N, Nicaise V, Knight CJ, Guillet-Descas E. Understanding parent stressors and coping experiences in elite sports contexts. Sport Exerc Perform Psychol. 2020;9 (3):390-404. doi

8. Ferreira RM, Moraes LC. Influência da família na primeira fase de desenvolvimento da carreira de nadadores medalhistas olímpicos brasileiros. Motricidade. 2012;8(2):42-51. doi

9. Nunomura M, Oliveira MS. A participação dos pais na carreira das atletas femininas de ginástica artística: a perspectiva dos técnicos. Rev Bras Educação Fis Esporte. 2014;28(1):125-34. doi

10. Anderson C, Kilpatrick S. Narrative interviewing. Int J Clin Pharm. 2016;38(3):631-4. doi

11. Minayo MCS. O desafio do conhecimento: pesquisa qualitativa em saúde. $14^{\circ}$ Ed. São Paulo, Ed. Hucitec; 2014.

12. Manzini EJ. Análise de entrevista. Marília, Ed. ABPEE; 2020.

13. Wilson SG, Wilson MJ, Baker J. Parental sport achievement and the development of athlete expertise. Eur J Sport Sci. 2019;19(5):661-70. doi.

14. Côté J. The influence of the family in the development of talent in sport. Sport Psychologist. 1999;13:305-417. doi.

15. Amado D, Sánchez-Oliva D, González-Ponce I, PulidoGonzález JJ, Sánchez-Miguel PA. Incidence of parental support and pressure on their children's motivational processes towards sport practice regarding gender. PLoS ONE. 2015;10(6):e0128015. doi

16. Costa VR, Oliveira MS, Carbinatto MV, Nunomura M. A motivação para as primeiras peripécias na ginástica artística: a perspectiva de praticantes iniciantes. Pensar a Prática. 2017;20(2):295-305. doi 
17. Krahenbühl T, Souza NP, Galatti LR, Scaglia AJ, Leonardo L. Competição de base e a formação de jovens atletas na perspectiva de treinadores de elite no handebol. Pensar a Prática. 2019;22:1-13. doi

18. Madigan DJ, Curran T, Stoeber J, Hill AP, Smith MM, Passfield L. Development of perfectionism in junior athletes: a three-sample study of coach and parental pressure. J Sport Exerc Psychol. 2019;41:167-75. doi

19. Fernandes FT. A influência do contexto familiar na formação de jovens atletas de futebol. Brasília, Ministério da Cidadania/Trampolim Editora; 2020.

20. Luna P, Guerrero J, Cejudo J. Improving adolescents' subjective well-being, trait emotional intelligence and social anxiety through a programme based on the sport education model. Int J Environ Res Public Health. 2019;16(10):1821. doi

21. Nakashima FS, Nascimento Junior JRA, Vissoci JRN, Vieira LF. Envolvimento parental no processo de desenvolvimento da carreira esportiva de atletas da seleção brasileira de ginástica rítmica: construção de um modelo explicativo. Rev Bras Ciencias Esporte. 2018;40(2):184-96. doi

22. Duarte LH, Carbinatto MV, Nunomura M. Artistic gymnastic and fear: reflections on it causes. Sci Gymnastics J. 2015;7(3):7-21.

23. Reis MO. O medo de falhar e as estratégias de coping utilizadas por jovens atletas de ginástica artística. Dissertação
[Mestrado em Ciências do Desporto], Universidade do Porto, Porto; 2011. https://repositorio-aberto.up.pt/handle/ $10216 / 56963$

24. Duarte LH, Ferreira Filho RA, Nunomura M. O medo na ginástica artística: treinamento e competição. Rev Mackenzie Educação Fis Esporte. 2008;7(2):51-67.

\section{Corresponding author}

Claudia Ridel Juzwiak, Universidade Federal de São

Paulo, Departamento de Ciências do Movimento Humano. Rua Silva Jardim, 136, sala 2A, 11015020 Santos, SP, Brazil.

E-mail: claudia.juzwiak@unifesp.br.

Manuscript received on January 8, 2021

Manuscript accepted on November 9, 2021

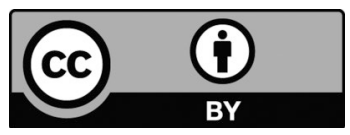

Motriz. The Journal of Physical Education. UNESP. Rio Claro, SP, Brazil - eISSN: 1980-6574 - under a license Creative Commons - Version 4.0 